\title{
Genotype by environment interaction of "carioca" seeded common bean advanced lines in northeastern Brazil
}

\section{Interação genótipos por ambientes em linhagens de feijoeiro-comum com grãos carioca, avaliadas na Região Nordeste do Brasil}

\author{
Helton Santos Pereira ${ }^{1 *}$; Renata Cristina Alvares ${ }^{2}$; Leonardo Cunha Melo ${ }^{1}$; \\ Antônio Félix da Costa ${ }^{3}$; Hélio Wilson Lemos de Carvalho ${ }^{4}$; \\ Luís Cláudio de Faria ${ }^{1}$; Thiago Lívio Pessoa Oliveira de Souza ${ }^{1}$
}

\begin{abstract}
The objectives of the present work were to identify common bean lines with high grain yield, adaptability and stability; stratify the environment; and detect the most important factors for the genotype by environment $(\mathrm{G} \times \mathrm{E})$ interaction in northeastern Brazil. Nineteen experiments were conducted in a randomized block design with three replications during the rainy growing season at 11 locations in the States of Pernambuco, Alagoas, Sergipe, and Bahia in 2009 and 2010. In each experiment, 16 "carioca" seeded lines were evaluated, and the grain yield, assessed. Data were subjected to analyses of variance and adaptability and stability by the methodologies of Annicchiarico and Additive Main Effects and Multiplicative Interactions (AMMI), analysis of the factors for environmental stratification and joint analysis with decomposition of the $\mathrm{G} \times \mathrm{E}$ interaction in genotype by year and genotype by location. According to the AMMI method, BRS Estilo and CNFC 11951 were selected as stable high-yielding lines. CNFC 11954, IPR Juriti, CNFC 11948 and BRS Estilo were identified as stable high-yielding lines based on the methodology of Annicchiarico. BRS Estilo was identified as stable according to both methodologies and was therefore considered suitable for growth in the Northeast region for use as a parent line in regional breeding programs. The locations in this region used to test the common bean lines were informative, except Carira, which could be eliminated from the assay network. Interaction among genotypes, locations and years were observed, suggesting that assessments shoud be conducted at the largest number of locations and years, in this order of importance.
\end{abstract}

Key words: Phaseolus vulgaris L. Grain yield. Environmental stratification. Stability.

\section{Resumo}

Os objetivos desse trabalho foram identificar linhagens de feijoeiro-comum com alta adaptabilidade e estabilidade de produção, realizar a estratificação ambiental e identificar quais fatores são mais importantes para a interação genótipos $\times$ ambientes $(\mathrm{G} \times \mathrm{E})$ na Região Nordeste do Brasil. Foram realizados 19 ensaios em blocos ao acaso, com três repetições, conduzidos na época de semeadura das águas, em 11 locais nos Estados de Pernambuco, Alagoas, Sergipe e Bahia, em 2009 e 2010. Os ensaios foram compostos por 16 linhagens de grão carioca e foram obtidos dados de produtividade de grãos. Os dados foram submetidos às análises de variância, à análise de adaptabilidade e estabilidade pelas

\footnotetext{
${ }^{1}$ Pesquisadores, Empresa Brasileira de Pesquisa Agropecuária, Embrapa Arroz e Feijão, Santo Antônio de Goiás, GO, Brasil. E-mail: helton.pereira@embrapa.br; leonardo.melo@embrapa.br; luis.faria@embrapa.br; thiago.souza@embrapa.br

2 Discente, Curso de Doutorado, Universidade Federal de Goiás, UFG, Goiânia, GO, Brasil. E-mail: renataalvares08@hotmail. com

3 Pesquisador, Instituto Agronômico de Pernambuco, IPA, Recife, PE, Brasil. E-mail: felix.antonio@ipa.br

${ }^{4}$ Pesquisador, Embrapa Tabuleiros Costeiros, Aracaju, SE, Brasil. E-mail: helio.carvalho@embrapa.br

* Author for correspondence
} 
metodologias de Annicchiarico e AMMI, à análise de fatores para estratificação ambiental e à análise conjunta com decomposição da interação $\mathrm{G} \times \mathrm{E}$ em genótipos $\times$ anos e genótipos $\times$ locais. As linhagens BRS Estilo e CNFC 11951 apresentam alta produtividade e estabilidade, pela metodologia AMMI. As linhagens CNFC 11954, IPR Juriti, CNFC 11948 e BRS Estilo apresentam alta produtividade e estabilidade, pela metodologia de Annicchiarico. BRS Estilo foi identificada como estável pelas duas metodologias, sendo, portanto, indicada para semeadura na Região Nordeste e para utilização como genitor em programas de melhoramento que visam o lançamento de cultivares para essa região. Os locais utilizados para avaliação de feijoeiro-comum nessa região são informativos, exceto Carira, que poderá ser eliminado da rede. Existe interação entre os genótipos, locais e anos nessa região, o que faz com que as avaliações sejam realizadas no maior número possível de locais e anos, nessa ordem de importância.

Palavras-chave: Phaseolus vulgaris L. Produtividade de grãos. Estratificação ambiental. Estabilidade.

\section{Introduction}

Brazil is one of the largest producers and consumers of common bean (Phaseolus vulgaris L.) grains worldwide, with an output of approximately 2.7 million tons of bean grains in 2011 (FEIJÃO, 2014). Common bean is part of the basic diet of the Brazilian population, particularly low-income groups. In 2011, 220,240 tons of common bean were produced on 438,091 ha in northeastern Brazil. In this region, the States of Bahia, Sergipe, Alagoas and Pernambuco are the largest common bean producers, and bean production is concentrated during the rainy season (sowing between February and April), primarily on small farms with subsistence level farming. This production, 524,182 tons in 1992, has decreased over the years.

The grain yield in the Northeast $\left(503 \mathrm{~kg} \mathrm{ha}^{-1}\right)$ is far below the national average yield $(1,354 \mathrm{~kg}$ $\mathrm{ha}^{-1}$ ) (FEIJÃO, 2014). One explanation for this low output is the use of old, low-yielding cultivars susceptible to biotic and abiotic stresses, reflecting the fact that few breeding programs have recently been active in this region. Thus, it is important to identify new, more productive, and regionally welladapted lines for growth by local farmers and for use as parents by regional breeding programs.

In northeastern Brazil, the common bean is grown in different cropping systems, and consequently, the effects of the genotype by environment $(\mathrm{G} \times \mathrm{E})$ interaction are relevant, as reported in several studies, especially for grain yield (RAMALHO et al., 1998;
GONÇALVES et al., 2009). Thus, alternatives to mitigate the effects of the $\mathrm{G} \times \mathrm{E}$ interaction are needed, among which the following are promising: identification of adapted/stable lines by analytical stability/adaptability methodologies, identification and elimination of locations providing redundant information using environmental stratification and partitioning of $\mathrm{G} \times \mathrm{E}$ interactions into factors to identify the most important parameters.

Studies of stability/adaptability have contributed to the recommendation of common bean cultivars for different regions (GONÇALVES et al., 2009; PEREIRA et al., 2009b). However, few studies focusing on this crop have been conducted in northeastern Brazil (CARVALHO et al., 2008; PEREIRA et al., 2013). Among the methodologies used for stability/adaptability analyses, the Annicchiarico (1992) method evaluates agronomic stability based on the risks associated with the adoption of a genotype and also facilitates the classification of this information into favorable and unfavorable environments. Another methodology used in stability studies is Additive Main Effects and Multiplicative Interactions (AMMI) (ZOBEL et al., 1988), which facilitates a more detailed analysis of the $\mathrm{G} \times \mathrm{E}$ interaction. These two methods are weakly correlated and can therefore be used simultaneously (SILVA; DUARTE, 2006; PEREIRA et al., 2009a).

Studies on the environmental stratification of the common bean have been carried out in some regions, such as São Paulo (CARBONELL; POMPEU, 1997), Paraná/Santa Catarina (BERTOLDO et al., 
2009; PEREIRA et al., 2010a) and Goiás/Distrito Federal (PEREIRA et al., 2010b). However, studies in the Northeast region are scarce and limited to the State of Pernambuco (PEREIRA et al., 2013). Similarly, studies addressing the decomposition of the $\mathrm{G} \times \mathrm{E}$ interaction have been conducted in Minas Gerais (RAMALHO et al., 1998), Paraná/ Santa Catarina (PEREIRA et al., 2010c; TORGA et al., 2013a), and Goiás/Distrito Federal (PEREIRA et al., 2011; TORGA et al., 2013b), but only one study has been conducted in the northeast region, in Pernambuco (PEREIRA et al., 2013).

Thus, the objective of the present work was to analyze the genotype by environment interaction in northeastern Brazil, identifying common bean lines with high grain yields, adaptability and stability; redundant locations in the tested assay networks; and the factors that are most important for these interaction.

\section{Materials and Methods}

Each field trial comprised 16 "carioca" seeded common bean lines, including 12 pre-commercial lines (CNFC 11944, CNFC 11945, CNFC 11946, CNFC 11948, CNFC 11951, CNFC 11952, CNFC 11953, CNFC 11954, CNFC 11956, CNFC 11959 , CNFC 11962, and CNFC 11966) and four cultivar controls (BRS Cometa, BRS Estilo, Pérola and IPR Juriti). Among the controls, the cultivar Pérola remains the most planted in Brazil, including the Northeast region, and BRS Estilo is a new cultivar with good performance in the Northeast region. The trials were carried out in 2009 and 2010 in 19 environments located in the States of Pernambuco, Alagoas, Bahia and Sergipe, during the rainy season (sowing between February and May), without supplemental irrigation. The experiments were designed in randomized blocks with three replications and plots comprising four rows of 4.0 $\mathrm{m}$ in length, spaced $0.5 \mathrm{~m}$ apart. The following environments were used: São João/PE (lat $08^{\circ} 52^{\prime}$ S, long $36^{\circ} 22^{\prime} \mathrm{W}$; $716 \mathrm{~m}$ ), Caruaru/PE (08 $17^{\circ}, 35^{\circ} 58^{\prime}$;
$554 \mathrm{~m})$, Arcoverde/PE $\left(08^{\circ} 25^{\prime}, 3^{\circ} 03^{\prime}, 663 \mathrm{~m}\right)$, Belém do São Francisco/PE (08²45', 3857', 305 $\mathrm{m})$, Coronel João Sá/BA (10¹7', 3755', $200 \mathrm{~m})$, Paripiranga/BA $\left(10^{\circ} 41^{\prime}, 37^{\circ} 51^{\prime}, 434 \mathrm{~m}\right)$, Carira/SE $\left(10^{\circ} 21^{\prime}, 37^{\circ} 42^{\prime}, 351 \mathrm{~m}\right)$, and Arapiraca/AL (09 45 , $\left.36^{\circ} 39^{\prime}, 264 \mathrm{~m}\right)$, in the rainy seasons of 2009 and 2010; Araripina/PE (07³4', 40²9'; $622 \mathrm{~m})$, in the rainy season of 2009; and Frei Paulo/SE (10 32 ', $\left.37^{\circ} 42^{\prime}, 272 \mathrm{~m}\right)$ and Petrolina/PE (09 $23^{\circ}, 40^{\circ} 30^{\prime}$, $376 \mathrm{~m}$ ), in the rainy season of 2010 .

Grain yield $\left(\mathrm{kg} \mathrm{ha}{ }^{-1}\right)$ was evaluated in all experiments, and the data for each trial were subjected to analysis of variance, considering the effect of treatments as fixed. The means of the lines were compared by the Scott-Knott test at $10 \%$ probability. In addition, to evaluate experimental precision, selective accuracy was estimated (RESENDE; DUARTE, 2007) by the following estimator:

$$
\mathrm{AS}=\left(1-\frac{1}{F_{c}}\right)^{0,5}
$$

for $F_{c}<1$, where $F_{c}$, is the calculated value of the $F$ test for lines.

Joint analysis of the trials was performed for each year separately and both years together, considering the environmental effect to be random. A joint analysis of the 16 experiments was also performed at eight locations where the trials were carried out in both years to partition the $\mathrm{G} \times \mathrm{E}$ interaction into genotype by location and genotype by year. The programs Genes (CRUZ et al., 2013) and Sisvar (FERREIRA, 1999) were used to perform the statistical analyses.

To identify the contribution of each source of variation in the joint analysis, the contribution of each source to the total variance was estimated using the estimated coefficient of determination $\left(\mathrm{R}^{2}\right)$ based on the expression: 


$$
\mathrm{R}_{\mathrm{i}}^{2}=\frac{\mathrm{SS}_{\mathrm{i}}}{\mathrm{SS}_{\mathrm{t}}}
$$

where $\mathrm{SS}_{\mathrm{i}}$ is the sum of squares of the source of variation $\mathrm{i}$, and $\mathrm{SS}_{\mathrm{t}}$ is the total sum of squares.

For stability analysis, AMMI and Annicchiarico methods were adopted. The Annicchiarico methodology (ANNICCHIARICO, 1992) is based on the index of genotypic recommendation (Wi), estimated by: $\omega_{i}=\hat{\mu}_{i}-z_{(1-\alpha)} \hat{\sigma}_{z_{i}}$, considering all environments, where $\hat{\mu}_{i}$ is the mean percentage of genotype $\mathrm{i} ; \hat{\sigma}_{\mathrm{z}_{\mathrm{i}}}$ is the standard deviation of $\mathrm{z}_{\mathrm{ij}}$ values associated with the $\mathrm{i}^{\text {th }}$ genotype; and $\mathrm{z}_{(1-\mathrm{a})}$ is the percentage of the normal standard distribution function. The indices for the favorable (Wif) and unfavorable environments (Wiu) were also calculated. The confidence coefficient was set at $75 \%$, i.e., $\alpha=0.25$.

For AMMI analysis, a significance level of 1\% was considered, based on the criterion of the $F_{r}$ test of Cornelius et al. (1992). The identification of the most stable lines was based on the WAAS (Weighted Average of Absolute Scores) index of each line, which was derived from the average of the absolute scores for each line in each significant component and weighted by the percentage of explanation of each component, as described by Pereira et al. (2009b). Thus, the line with the lower WAAS is the most stable. Stability was also interpreted by graphical analysis with the line means and WAAS. Lines closer to zero on the ordinate axis are the most stable lines, whereas those further away contribute most to the interaction.

Environmental stratification analyses were performed separately for each year using factor analysis (MURAKAMI; CRUZ, 2004). The grouping of the environments was based on final load factors obtained after rotations greater than or equal to 0.70 with the same sign, indicating environments with high correlation that can be grouped into a single factor. According to Cruz and Carneiro (2006), the number of factors considered in the final environmental stratification in this analysis represents the number of eigenvalues that are greater than or equal to 1.0. However, when the proportion of variance explained by eigenvalues greater than 1.0 is relatively low, more factors are therefore considered until at least $80 \%$ of the total variability is reached..

\section{Results and Discussion}

The coefficients of variation ranged from $7.2 \%$ to $25.9 \%$ across the different environments, indicating good experimental precision, which was confirmed by the estimates of selection accuracy, which were considered high or very high (above 0.7 ) (CARGNELUTTI FILHO et al., 2009) for 11 of the 19 field trials and intermediate for five of these field trials. Mean yields ranged from 1,321 to $3,005 \mathrm{~kg}$ ha 1 , indicating high variability between environments. This observation was confirmed by the geographic data of the testing locations at altitudes between 200 and $716 \mathrm{~m}$, Southern latitudes from $8^{\circ} 17^{\prime}$ to $10^{\circ} 41^{\prime}$ and Western longitudes from $35^{\circ} 58^{\prime}$ to $40^{\circ} 30^{\prime}$. At locations with assays conducted in both years, the mean yield was lower in $2009\left(2,149 \mathrm{~kg} \mathrm{ha}^{-1}\right)$ than in $2010\left(2,293 \mathrm{~kg} \mathrm{ha}^{-1}\right)$. The joint analysis showed differences between lines and environments and also revealed the presence of $\mathrm{G} \times \mathrm{E}$ interaction, i.e., a differentiated performance of lines in distinct environments (Table 1). 
Table 1. Summary of the joint analysis of variance with partitioning of the $G \times E$ interaction by the AMMI method for 16 "carioca" seeded common bean lines evaluated in 19 environments in northeastern Brazil.

\begin{tabular}{lcrc}
\hline Source of variation & DF & MS & p-value \\
\hline Bloc/Environments & 38 & 171,951 & - \\
Lines (G) & 15 & 489,574 & 0.0029 \\
Environments (E) & 18 & $16,600,661$ & 0.0000 \\
G x E & 270 & 203,352 & 0.0000 \\
IPCA 1 & 32 & 442,662 & 0.0000 \\
Residue 1 & 238 & 171,165 & 0.0000 \\
IPCA 2 & 30 & 366,489 & 0.0000 \\
Residue 2 & 208 & 142,992 & 0.0000 \\
IPCA 3 & 28 & 299,955 & 0.0000 \\
Residue 3 & 180 & 118,575 & 0.0090 \\
IPCA 4 & 26 & 209,085 & 0.0003 \\
Residue 4 & 154 & 103,296 & 0.1301 \\
Residue & 570 & 90,105 & \\
\hline Mean & 2,259 & & \\
CV (\%) & 15.9 & & \\
\hline
\end{tabular}

DF: Degrees of freedom; MS: Mean square.

The stability analysis for grain yield based on the method of Annicchiarico (1992) for all environments identified four lines with Wi values above 100\% (Table 2). This result indicates a probability of $75 \%$ that the yield of these lines is above the environmental mean. The best lines were CNFC 11954 (101.8\%), IPR Juriti (101.6\%), CNFC 11966 (100.6\%), and CNFC 11948 (100.5\%), which are expected to produce $1.8 \%, 1.6 \%, 0.9 \%$, and $0.5 \%$ above the mean, respectively. In the unfavorable environments, good adaptation/stability was observed in five lines. Among these, CNFC 11966 is noteworthy, with $\mathrm{Wiu}=106.1$. The performance of three other lines, CNFC 11948 (103.4\%), CNFC 11956 (103.3\%) and CNFC 11951 (101.6\%), was also good. In the favorable environments, a Wif of more than 100\% was found for five lines: IPR Juriti (104.3\%), CNFC 11954 (103.9\%), CNFC 11945 (101.3\%), BRS Estilo (100.8\%), and CNFC 11962 (100.6\%).

To confirm the wide adaptability of the lines, we also observed whether the Wif (index of genotypic recommendation genotype in favorable environments) and Wiu (index of genotypic recommendation genotype in unfavorable environments) of a line were greater than $100 \%$. In this sense, IPR Juriti and CNFC 11954 were noteworthy, representing the most stable among the highest-yielding lines (Table 3). The indices of lines CNFC 11948 and BRS Estilo were also close to or greater than $100 \%$, suggesting that these lines were therefore suitable for use in any environment. Regarding the seven highest-yielding lines, the stability of five of these lines was good. The adaptability/stability of some lines was specific for a particular environment, such as CNFC 11966 $(\mathrm{Wiu}=106.1 \%$ and $\mathrm{Wif}=95.9 \%)$ for unfavorable environments and CNFC 11945 (Wiu $=92.1 \%$ and Wif $=101.3 \%$ ) for favorable environments. This differential adaptation of lines to certain regions is typical, as described in several previous studies, e.g., Pereira et al. (2009a, 2009b), in the Central and Central-South regions of Brazil, which also considered BRS Estilo to be the most stable/adapted line among the 16 evaluated. 
Table 2. Average grain yield and stability/adaptability parameters according to the AMMI and Annicchiarico methods for 16 "carioca" seeded common bean lines evaluated in 19 environments in the Northeast of Brazil.

\begin{tabular}{|c|c|c|c|c|c|c|c|c|c|c|c|}
\hline \multirow{2}{*}{ Lines } & \multirow{2}{*}{ Mean $^{1}$} & \multicolumn{6}{|c|}{ AMMI } & \multicolumn{4}{|c|}{ Annichiarico } \\
\hline & & IPCA1 & IPCA2 & IPCA3 & IPCA4 & MPEA $^{2}$ & $\mathrm{C}^{3}$ & $\mathrm{~W}_{i}^{4}$ & $\mathrm{C}$ & $\mathrm{W}_{\mathrm{if}}^{5}$ & $\mathrm{~W}_{\mathrm{id}}{ }^{6}$ \\
\hline CNFC 11954 & $2,421 \mathrm{a}$ & 29.9 & 3.8 & 4.7 & 19.3 & 15.7 & 16 & 101.8 & 1 & 103.9 & 99.9 \\
\hline IPR Juriti & $2,403 a$ & -23.3 & -14.0 & 0.3 & 16.8 & 14.8 & 15 & 101.6 & 2 & 104.3 & 99.1 \\
\hline CNFC 11966 & $2,370 \mathrm{a}$ & -14.3 & 6.2 & 27.4 & 1.5 & 13.0 & 14 & 100.6 & 3 & 95.9 & 106.1 \\
\hline CNFC 11948 & $2,334 \mathrm{a}$ & -9.9 & 14.4 & 1.6 & 2.4 & 8.4 & 10 & 100.5 & 4 & 98.1 & 103.4 \\
\hline BRS Estilo & $2,302 \mathrm{a}$ & -7.1 & -7.2 & -8.3 & -0.8 & 6.5 & 6 & 99.7 & 5 & 100.8 & 98.4 \\
\hline CNFC 11945 & $2,279 \mathrm{a}$ & 3.6 & -25.7 & 4.6 & -9.1 & 10.8 & 13 & 96.8 & 10 & 101.3 & 92.1 \\
\hline CNFC 11951 & $2,278 \mathrm{a}$ & 0.1 & 3.5 & 1.3 & 3.6 & 1.8 & 1 & 99.0 & 6 & 96.8 & 101.6 \\
\hline CNFC 11962 & $2,256 \mathrm{~b}$ & 3.2 & -3.9 & -3.2 & -7.6 & 4.0 & 2 & 97.3 & 8 & 100.6 & 94.0 \\
\hline CNFC 11956 & $2,242 b$ & -1.7 & 19.1 & -14.0 & -8.6 & 10.2 & 12 & 97.7 & 7 & 93.2 & 103.3 \\
\hline CNFC 11953 & $2,231 b$ & 3.1 & 4.4 & 5.8 & -11.7 & 5.2 & 4 & 97.1 & 9 & 94.3 & 100.3 \\
\hline Pérola & $2,225 b$ & -9.8 & 2.1 & -20.0 & 9.7 & 9.8 & 11 & 95.2 & 13 & 97.7 & 92.4 \\
\hline CNFC 11946 & $2,209 b$ & -4.1 & 6.0 & 0.1 & -12.8 & 5.0 & 3 & 95.3 & 11 & 95.2 & 95.7 \\
\hline CNFC 11952 & $2,207 \mathrm{~b}$ & 6.3 & 11.9 & 6.8 & 4.0 & 7.7 & 9 & 95.2 & 12 & 93.3 & 97.9 \\
\hline BRS Cometa & $2,184 b$ & 6.6 & -6.2 & 3.9 & -2.0 & 5.3 & 5 & 93.2 & 14 & 97.4 & 89.1 \\
\hline CNFC 11944 & $2,129 b$ & 8.4 & -9.1 & -0.7 & -6.2 & 6.6 & 7 & 91.1 & 15 & 93.4 & 88.7 \\
\hline CNFC 11959 & $2,081 \mathrm{~b}$ & 8.9 & -5.4 & -10.3 & 1.6 & 7.2 & 8 & 90.0 & 16 & 90.2 & 89.9 \\
\hline
\end{tabular}

${ }^{1}$ Yield means $\left(\mathrm{kg} \mathrm{ha}^{-1}\right)$ followed by the same letter do not differ by the Scott-Knott test at 10\% probability; ${ }^{2}$ Weighted average of absolute scores; ${ }^{3}$ Stability classification of lines; \% Explanation of the significant components IPCA1 (25.8), IPCA2 (20.0), IPCA3 (15.3), IPCA 4(9.9); ${ }^{4}$ Genotypic confidence index; ${ }^{5}$ Genotypic confidence index in favorable environments; ${ }^{6}$ Genotypic confidence index in unfavorable environments.

Table 3. Summary of joint analysis of variance for grain yield for 16 "carioca" seeded common bean lines evaluated in 16 environments in the Northeast of Brazil, with partitioning of the $\mathrm{G} \times \mathrm{E}$ interaction.

\begin{tabular}{lrrrrr}
\hline Source of variation & DF & SS & MS & p-value & $\mathrm{R}^{2}(\%)$ \\
\hline Bloc/environment & 32 & $5,882,037$ & 183,814 & 0.0009 & 1.6 \\
Genotypes (G) & 15 & $5,332,850$ & 355,523 & 0.0000 & 1.4 \\
Locals (L) & 7 & $219,506,839$ & $31,358,120$ & 0.0000 & 59.3 \\
Years (Y) & 1 & $3,978,145$ & $3,978,145$ & 0.0000 & 1.1 \\
G x L & 105 & $19,150,072$ & 182,382 & 0.0000 & 5.2 \\
G x Y & 15 & $2,478,462$ & 165,231 & 0.0289 & 0.7 \\
L x Y & 7 & $51,741,713$ & $7,391,673$ & 0.0000 & 14.0 \\
G x L x Y & 105 & $18,667,103$ & 177,782 & 0.0000 & 5.0 \\
Residue & 480 & $43,462,620$ & 90,547 & - & - \\
\hline Total & 767 & $370,199,841$ & & - & - \\
\hline Mean & 2,221 & & & & - \\
CV $(\%)$ & 13.6 & & & &
\end{tabular}

DF: Degrees of freedom; SS: Sum of squares; MS: Mean square; $\mathrm{R}^{2}$ : Coefficient of determination.

Regarding the AMMI analysis, Chaves (2001) reported that the appropriate model would associate significance with the axes and non-significance with the residues. Based on this criterion, the model AMMI 4 was selected (Table 1). The first two axes together explained $71.0 \%$ of the variation, exceeding the values reported by Carbonell et al. (2004) and Pereira et al. (2009b). Thus, the most stable lines were identified based on the information in the first four components, using the WAAS of 
each line (Table 3). The use of this parameter as a stability measure allows the representation of the stability and mean yield of lines in a single diagram, facilitating the simultaneous analysis of the two parameters (PEREIRA et al., 2009b). The WAAS parameter showed only positive values, and based on the WAAS, the lines with lower values (next to zero) were considered the most stable (CNFC 11951, CNFC 11962, CNFC 11946, CNFC 11953, and BRS Cometa) (Table 3) (Figure 1). CNFC 11954, IPR Juriti and CNFC 11966 were the least stable of the highest-yielding lines. Regarding the seven highest-yielding lines, only two were among the most stable (CNFC 11951 and BRS Estilo).

Figure 1. Diagram of AMMI model of the common bean lines: G1- Pérola; G2 - BRS Cometa; G3 - IPR Juriti; G4 BRS Estilo; G5 - CNFC 11944; G6 - CNFC 11945; G7 - CNFC 11946; G8 - CNFC 11948; G9 - CNFC 11951; G10 - CNFC 11952; G11 - CNFC 11953; G12 - CNFC 11954; G13 - CNFC 11956; G14 - CNFC 11959; G15 - CNFC 11962; G16 - CNFC 11966. Field trials conducted in 19 environments in northeastern Brazil. Average yield $\left(\mathrm{kg} \mathrm{ha}^{-1}\right)$ and the weighted average of absolute scores (WAAS) for each line.

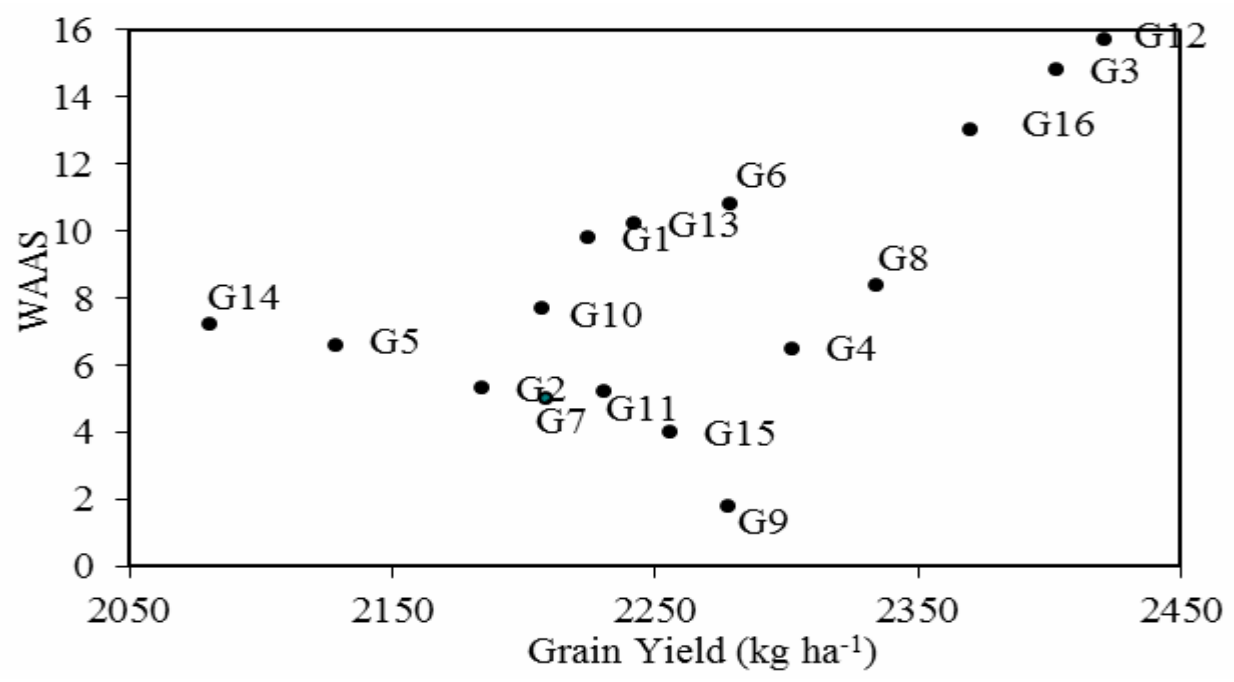

The partitioning analysis of the $\mathrm{G} \times \mathrm{E}$ interaction in genotype by year $(\mathrm{G} \times \mathrm{Y})$ and genotype by location $(\mathrm{G} \times \mathrm{L})$ detected significant differences for all sources of variation (Table 3). Although differences between lines have been reported, the major differences among the principal sources of variation were detected more for locations than for lines and years, as indicated by the $\mathrm{R}^{2}$ values. In works on common bean breeding conducted in Paraná/Santa Catarina and Goiás/Distrito Federal, respectively, Pereira et al. (2010c, 2011) showed that the sources of variation for lines and years were more important than those for locations. Torga et al. (2013a, 2013b) also conducted studies in the abovementioned States, showing increased relevance for the source of variation for years. However, Ramalho et al. (1998) in Minas Gerais and Pereira et al. (2013) in Pernambuco showed greater importance for locations and years than for lines. Notably, more locations (eight) were used in this study than in those mentioned above, increasing the chance of greater variation between locations.

The $\mathrm{G} \times \mathrm{L}$ and $\mathrm{G} \times \mathrm{Y}$ interactions were significant, representing $5.2 \%$ and $0.7 \%$ of the total variation (Table 3), respectively, indicating that the $\mathrm{G} \times \mathrm{L}$ interaction is 7.4 times greater and, consequently, more important. In other words, this result likely indicates that evaluations of more locations are more important than evaluations of more years, consistent with the results of Pereira et al. (2010c, 2013). Ramalho et al. (1998) reported similar $R^{2}$ values for these interactions. However, Pereira et 
al. (2011) and Torga et al. (2013a, 2013b) showed that the $\mathrm{G} \times \mathrm{Y}$ interaction is more important than the $\mathrm{G} \times \mathrm{L}$ interaction. In general, there is wide variation in the importance of these two sources of variation, depending on the respective study areas, locations and years, which explains why there is no consensus on which source is the most important. The results of this study indicate the existence of interaction between lines, locations and years, in northeastern Brazil. Thus, the lines should be evaluated at the largest possible number of locations and years, in this order of importance, for a more reliable recommendation of lines as new cultivars.

The analyses of variance for each year also identified the significant effects of lines, locations and interaction, enabling environmental stratification. In 2009, five final factors were considered, explaining $85.3 \%$ of the total variation (Table 4). The geographically close locations Carira/ SE (-0.75) and Paripiranga/BA (-0.83) were grouped into a third factor. Arcoverde (0.84) and Araripina (0.87), both in Pernambuco, were clustered into a fourth factor. In 2010, five factors were also used, explaining $79.5 \%$ of the total variance. Clustering occurred in only the first factor, with Coronel João Sá/BA (0.91), Carira/SE (0.78), and Frei Paulo/SE (0.79).

The redundancy between locations in 2009 was not confirmed in 2010. However, there was a tendency to cluster geographically adjacent locations in Sergipe and Bahia, as in the case of Carira/SE, which was grouped with Paripiranga/BA in 2009 and Coronel João Sá/BA and Frei Paulo/ $\mathrm{SE}$ in 2010. In this case, Carira was considered the least informative location. The only clusters among locations in different States (Bahia, Alagoas, Sergipe, and Pernambuco) were those between geographically close locations, further highlighting the importance of evaluations in different States.

Pereira et al. (2013) also stratified the environment in common bean line evaluations, considering only locations in Pernambuco, in 2007 and 2008. These authors identified clusters between São João and Arcoverde in only one of the years of evaluation. In the present study, no association between these two locations was identified. An association was found between Arcoverde and Araripina only in 2009, suggesting that the locations in Pernambuco are informative. In general, it was concluded that the locations used (Table 4) were informative and should be maintained in the evaluation assay network of the Northeast region as no consistent similarity patterns between locations were observed over the years, except for Carira/SE, which can be substituted by another location. Thus, it is important to mention that the incorporation of new locations is desirable because important $\mathrm{G} \times \mathrm{L}$ interactions were detected (Table 3). 
Table 4. Environmental stratification based on grain yield, based on an analysis of the factors per year, for 16 "carioca" seeded common bean lines evaluated in 19 environments in the Northeast of Brazil in 2009 and 2010.

\begin{tabular}{|c|c|c|c|c|c|c|c|c|c|}
\hline \multicolumn{3}{|c|}{ Eigenvalues } & \multicolumn{7}{|c|}{ Load factors obtained after rotation } \\
\hline Factor & $\lambda^{1}$ & $\%^{2}$ & Environments & Factor 1 & Factor 2 & Factor 3 & Factor 4 & Factor 5 & $\Phi^{3}$ \\
\hline \multicolumn{10}{|c|}{ Rainy/2009 } \\
\hline 1 & 2.58 & 28.7 & CARU-PE & 0.33 & 0.58 & 0.56 & 0.30 & -0.17 & 0.88 \\
\hline 2 & 1.95 & 50.4 & SÃOJ-PE & 0.86 & 0.02 & -0.08 & 0.41 & 0.04 & 0.92 \\
\hline 3 & 1.37 & 65.6 & ARCO-PE & 0.18 & -0.22 & 0.11 & 0.84 & 0.30 & 0.89 \\
\hline 4 & 0.94 & 76.1 & BELE-PE & -0.10 & 0.14 & -0.09 & 0.05 & 0.93 & 0.90 \\
\hline 5 & 0.82 & 85.3 & ARAR-PE & 0.05 & 0.17 & -0.15 & 0.87 & -0.16 & 0.84 \\
\hline- & - & - & CORO-BA & -0.27 & 0.80 & -0.26 & -0.10 & 0.34 & 0.91 \\
\hline- & - & - & CARI-SE & -0.15 & 0.21 & -0.75 & 0.04 & 0.29 & 0.72 \\
\hline- & - & - & PARI-BA & 0.16 & 0.00 & -0.83 & 0.08 & -0.11 & 0.73 \\
\hline- & - & - & ARAP-AL & -0.91 & 0.14 & -0.06 & 0.07 & 0.18 & 0.89 \\
\hline \multicolumn{10}{|c|}{ Rainy/2010 } \\
\hline 1 & 2.89 & 28.9 & ARAP-AL & 0.34 & -0.03 & -0.76 & 0.26 & 0.01 & 0.76 \\
\hline 2 & 1.58 & 44.7 & CORO-BA & 0.91 & -0.01 & 0.14 & -0.01 & -0.01 & 0.85 \\
\hline 3 & 1.39 & 58.6 & PARI-BA & 0.41 & -0.72 & 0.07 & 0.03 & -0.08 & 0.70 \\
\hline 4 & 1.17 & 70.3 & CARI-SE & 0.78 & 0.06 & -0.31 & 0.19 & -0.35 & 0.86 \\
\hline 5 & 0.92 & 79.5 & FREI-SE & 0.79 & -0.27 & -0.29 & 0.06 & 0.24 & 0.85 \\
\hline - & - & - & BELE-PE & 0.11 & 0.80 & 0.02 & -0.04 & -0.19 & 0.70 \\
\hline- & - & - & ARCO-PE & -0.08 & -0.22 & -0.05 & 0.90 & -0.08 & 0.88 \\
\hline- & - & - & SÃOJ-PE & 0.37 & 0.29 & 0.11 & 0.59 & 0.02 & 0.58 \\
\hline- & - & - & CARU-PE & -0.01 & -0.11 & 0.03 & -0.05 & 0.97 & 0.96 \\
\hline - & - & - & PET-PE & 0.09 & -0.04 & 0.86 & 0.20 & 0.05 & 0.80 \\
\hline
\end{tabular}

${ }^{1}$ Eigenvalues; ${ }^{2}$ Percentage of cumulative variation explained by the eigenvalues; ${ }^{3}$ Communalities.

\section{Conclusions}

The genotype by environment interaction is important for common bean yield in northeastern Brazil. In this region, the effect of the interaction between common bean lines, locations and years is significant, and consequently, the lines should be evaluated at the largest possible number of locations and for as many years as possible, in this order of importance.

BRS Estilo and CNFC 11951 were high-yielding and stable lines, according to the AMMI method. According to the methodology of Annicchiarico, CNFC 11954, IPR Juriti, CNFC 11948, and BRS Estilo were high-yielding and stable lines. BRS Estilo was indicated as stable by both methodologies; therefore, this line was suitable for cultivation in the Northeast region of Brazil and for use as a parent line in breeding programs aiming to develop new cultivars for this region.
The locations São João, Caruaru, Arco Verde, Belém do São Francisco, Petrolina, and Araripina, in Pernambuco; Arapiraca, in Alagoas; Frei Paulo, in Sergipe; and Coronel João Sá and Paripiranga, in Bahia, provide additional information for the evaluation of common bean lines in Northeast Brazil. The location Carira/SE is uninformative and could therefore be eliminated from the evaluation assay network.

\section{Acknowledgements}

The authors wish to thank Embrapa Arroz e Feijão, Embrapa Tabuleiros Costeiros and the Agronomic Institute of Pernambuco (IPA), for funding and support to this work. The authors also thank the Brazilian Council for Scientific and Technological Development (CNPq) for funding and grants for technological development and 
innovative extension of the first and third authors and a D.Sc. scholarship of the second author.

\section{References}

ANNICCHIARICO, P. Cultivar adaptation and recommendation from alfafa trials in Northern Italy. Journal of Genetics and Plant Breeding, Roma, v. 46, n. 1, p. 269-278, 1992.

BERTOLDO, J. G.; COIMBRA, J. L. M.; NODARI, B. O.; GUIDOLIN, A. F.; HEMP, S.; BARILI, L. D.; VALE, N. M.; ROZZETO, D. S. Stratification of the state of Santa Catarina in macro-environments for bean cultivation. Crop Breeding and Applied Biotechnology, Viçosa, MG, v. 9, n. 4, p. 335-343, 2009.

CARBONELL, S. A. M.; AZEVEDO FILHO, J. A.; DIAS, L. A. S.; GARCIA, A. A. F.; MORAIS, L. K. Common bean cultivars and lines interactions with environments. Scientia Agricola, Piracicaba, v. 61, n. 2, p. 169-177, 2004.

CARBONELL, S. A. M.; POMPEU, A. S. Estratificação de ambientes em experimentos de feijoeiro no Estado de São Paulo. Bragantia, Campinas, v. 56, n. 1, p. 207-218, 1997.

CARGNELUTTI FILHO, A.; STORCK, L.; RIBEIRO, N. D. Medidas da precisão experimental em ensaios com genótipos de feijão e de soja. Pesquisa Agropecuária Brasileira, Brasília, v. 44, n. 10, p. 1225-1231, 2009.

CARVALHO, H. W. L.; FARIA, L. C.; DEL PELOSO, M. J.; RIBEIRO, F. E.; MELO, L. C.; OLIVEIRA, V. D.; RIBEIRO, S. S. Adaptabilidade e estabilidade de cultivares de feijoeiro comum na Zona Agreste do Nordeste Brasileiro. Agrotrópica, Ilhéus, v. 20, n. 1, p. 21-24, 2008.

CHAVES, L. J. Interação de genótipos com ambientes. In: NASS, L. L.; VALOIS, A. C. C.; MELO, I. S.; VALADARES-INGLES, M. C. Recursos genéticos e melhoramento: plantas. Rondonópolis: Fundação MT, 2001. p. 673-713.

CORNELIUS, P. L.; SEYEDSADR, M.; CROSSA, J. Using the shifted multiplicative model to search for separability in crop cultivar trials. Theoretical and Applied Genetics, Berlin, v. 84, n. 1, p. 161-172, 1992.

CRUZ, C. D. GENES - a software package for analysis in experimental statistics and quantitative genetics. Acta Scientiarum. Agronomy, Maringá, v. 35, n. 3, p. 271-276, 2013.
CRUZ, C. D.; CARNEIRO, P. C. Modelos biométricos aplicados ao melhoramento genético. Viçosa, MG: Editora UFV, 2006. v. 2, 585 p.

FEIJÃO: dados conjunturais do feijão (área, produção e rendimento) - Brasil - 1985 a 2009. Santo Antônio de Goiás: Embrapa, 2014. Disponível em: <http://www. cnpaf.embrapa.br/apps/socioeconomia/index.htm>. Acesso em: 20 maio 2014.

FERREIRA, D. F. Sistema para análise de variância para dados balanceados (SISVAR). Lavras: UFLA, 1999. $92 \mathrm{p}$.

GONÇALVES, J. G. R.; CHIORATO, A. F.; PERINA, E. F.; CARBONELL, S. A. M. Estabilidade fenotípica em feijoeiro estimada por análise ammi com genótipo suplementar. Bragantia, Campinas, v. 68, n. 4, p. 863871, 2009.

MURAKAMI, D. M.; CRUZ, C. D. Proposal of methodologies for environment stratification and analysis of genotype adaptability. Crop Breeding and Applied Biotechnology, Viçosa, MG, v. 4, n. 1, p. 7-11, 2004.

PEREIRA, H. S.; COSTA, A. F.; MELO, L. C.; DEL PELOSO, M. J.; FARIA, L. C. de; WENDLAND, A. Interação entre genótipos de feijoeiro e ambientes no Estado de Pernambuco: estabilidade, estratificação ambiental e decomposição da interação. Semina. Ciências Agrárias, Londrina, v. 34, n. 6, p. 2603-2614, 2013.

PEREIRA, H. S.; MELO, L. C.; DEL PELOSO, M. J.; FARIA, L. C. de; COSTA, J. G. C. da; DÍAZ, J. L. C.; RAVA, C. A.; WENDLAND, A. Comparação de métodos de análise de adaptabilidade e estabilidade fenotípica em feijoeiro-comum. Pesquisa Agropecuária Brasileira, Brasília, v. 44, n. 4, p. 374-383, 2009a.

PEREIRA, H. S.; MELO, L. C.; DEL PELOSO, M. J.; FARIA, L. C. de; WENDLAND, A. Complex interaction between genotypes and growing seasons of carioca common bean in goiás/distrito federal. Crop breeding and applied biotechnology, Viçosa, MG, v. 10, n. 3, p. 207-215, 2011.

PEREIRA, H. S.; MELO, L. C.; FARIA, L. C. de; DEL PELOSO, M. J.; COSTA, J. G. C.; RAVA, C. A.; WENDLAND, A. Adaptabilidade e estabilidade de genótipos de feijoeiro-comum com grãos tipo carioca na Região Central do Brasil. Pesquisa Agropecuária Brasileira, Brasília, v. 44, n. 1, p. 29-37, 2009b.

PEREIRA, H. S.; MELO, L. C.; FARIA, L. C. de; DEL PELOSO, M. J.; DÍAZ, J. L. C.; WENDLAND, A. Indicação de cultivares de feijoeiro-comum baseada na avaliação conjunta de diferentes épocas de semeadura. Pesquisa Agropecuária Brasileira, Brasília, v. 45, n. 6, p. 571-578, 2010c. 
PEREIRA, H. S.; MELO, L. C.; FARIA, L. C. de; DEL PELOSO, M. J.; WENDLAND, A. Environmental Stratification in Paraná and Santa Catarina States to evaluate common bean genotypes. Crop Breeding and Applied Biotechnology, Viçosa, MG, v. 10, n. 2, p. 132139, 2010a.

. Estratificação ambiental na avaliação de genótipos de feijoeiro-comum tipo Carioca em Goiás e no Distrito Federal. Pesquisa Agropecuária Brasileira, Brasília, v. 45, n. 6, p. 554-562, 2010 b.

RAMALHO, M. A. P.; ABREU, A. F. B.; SANTOS, P. S. J. Interações genótipos x épocas de semeadura, anos e locais na avaliação de cultivares de feijão nas Regiões Sul e Alto Paranaíba em Minas Gerais. Ciência e Agrotecnologia, Lavras, v. 22, n. 2, p. 176-181, 1998.

RESENDE, M. D. V.; DUARTE, J. B. D. Precisão e controle de qualidade em experimentos de avaliação de cultivares. Pesquisa Agropecuária Tropical, Goiânia, v. 37, n. 2, p. 182-194, 2007.
SILVA, W. C. J.; DUARTE, J. B. Métodos estatísticos para estudo de adaptabilidade e estabilidade fenotípica em soja. Pesquisa Agropecuária Brasileira, Brasília, v. 41, n. 1, p. 23-30, 2006.

TORGA, P. P.; MELO, P. G. S.; PEREIRA, H. S.; FARIA, L. C.; DEL PELOSO, M. J.; MELO, L. C. Decomposition of the interaction of common black bean group genotypes with the environment. Agricultural Sciences, Irvine, v. 4, n. 12 , p. $683-688,2013$ b.

Interaction of common bean cultivars of the black group with years, locations and sowing seasons. Euphytica, Wageningen, v. 189, n. 2, p. 239-248, 2013a.

ZOBEL, R. W.; WRIGHT, M. J.; GAUCH, H. G. Statistical analysis of a yield trial. Agronomy Journal, Madison, v. 80, n. 3, p. 388-393, 1988. 
